\title{
First report of a newly naturalized Sisyrinchium micranthum and a taxonomic revision of Sisyrinchium rosulatum in Korea
}

\author{
Hye Woo Shin, Myoung Jun Kim ${ }^{1}$ and Nam Sook Lee* \\ Interdisciplinary Program of EcoCreative, The Graduate School, Ewha Womans University, Seoul 03760, Korea \\ ${ }^{1}$ Yeomiji Botanical Garden, Jeju 63535, Korea \\ ${ }^{2}$ Department of Life Science, Ewha Womans University, Seoul 03760, Korea
}

(Received 31 July 2016; Revised 5 September 2016; Accepted 10 September 2016)

\section{한국 미기록 귀화식물 연등심붓꽃과 등심붓꽃의 분류학적 재검토}

\author{
신혜우 · 김명준 ${ }^{1}$ - 이남숙 ${ }^{2 *}$ \\ 이화여자대학교 대학원 에코크리에이티브 협동과정, ${ }^{1}$ 여미지식물원, ${ }^{2}$ 이화여자대학교 생명과학과
}

\begin{abstract}
Sisyrinchium micranthum Cav., a newly naturalized species, was found in Seogwipo, Jeju-do. This species is native to Central and South America and is reported as a widely invasive species around the world. Sisyrinchium micranthum is a sister species of S. rosulatum E. P. Bicknell (Deung-Sim-But-Kkot in Korean), reported as an invasive species earlier in Korea, and both species are members of the subgenus Echthronema. Sisyrinchium micranthum is distinguished from S. rosulatum by the urceolate shape of its flowers and by the large size of its fruits and seeds. Its local name is "Yeon-Deung-Sim-But-Kkot" based on the lavender color corolla. We also found that Sisyrinchium angustifolium Mill., previously used for Deung-Sim-But-Kkot, was misapplied. It belongs to the subgenus Sisyrinchium and is morphologically very different from S. rosulatum. We corrected the scientific name of Deung-Sim-But-Kkot by changing it from S. angustifolium to S. rosulatum based on the type specimens, original descriptions, and recent studies.
\end{abstract}

Keywords: Sisyrinchium micranthum, Sisyrinchium rosulatum, Iridaceae, naturalized plants

적 요: 제주도 서귀포시 일대에서 미기록 귀화식물 연등심붓꽃 (Sisyrinchium micranthum Cav.)이 발견되었 다. 이 종은 중남미가 원산이며 여러 나라에서 침입종으로 보고된 바 있다. 연등심붓꽃은 국내에 먼저 보고 된 귀화식물인 등심붓꽃의 자매종이며 두 종 모두 Echthronema 아속에 속한다. 연등심붓꽃은 화관의 밑부분 이 긴 항아리 모양, 열매와 씨가 큰 점에 의해 등심붓꽃과 구별된다. 꽃이 연보라색이어서 국명을 연등심붓 꽃이라고 신칭하였다. 등심붓꽃의 이전 학명인 S. angustifolium Mill.은 Sisyrinchium 아속에 속하는 종이며 형태적으로 등심붓꽃 (S. rosulatum)과 매우 상이하다. 등심붓꽃의 학명을 기준표본, 원기재문, 최근의 논문들 을 근거로 S. angustifolium Mill. 에서 S. rosulatum E. P. Bicknell 으로 변경한다.

주요어: 연등심붓꽃, 등심붓꽃, 붓꽃과, 귀화식물

Sisyrinchium L. contains many species and it is the most taxonomically complicated genus in Iridaceae. The number of species in Sisyrinchium varies from ca. 60 to ca. 200 according to taxonomists (Rudall et al., 1986; Goldblatt et al., 1989, 2004). Sisyrinchium needs more research to resolve subgeneric divisions, identification of species, and synonyms for uncertain

\footnotetext{
*Author for correspondence: namsook@ewha.ac.kr
} 
species (Goldblatt et al., 1990; Cocucci and Vogel, 2001; Souza-Chies et al., 2012; Alves et al., 2014). Most species are native to the New World and some species were reported as weedy and invasive plants in many countries (Esler and Astridge, 1987; Space and Flynn, 2002; Macdonald et al., 2003; Miyawaki and Washitani, 2004; Weber and Gut, 2004; Wu et al., 2004).

According to previous studies, genus Sisyrinchium was divided into two subgenera Sisyrinchium and Echthronema (Cholewa and Henderson, 1984; Rudall et al., 1986; Goldblatt et al., 1989, 1990; Cocucci and Vogel, 2001). Sisyrinchium micranthum Cav. and S. rosulatum E. P. Bicknell were assigned to subgenus Echthronema and they have partially fused filaments which is the main characteristic of subgenus Echthronema. These two species additionally have common characteristics of subgenus Sisyrinchium like blue to purplish tepals and basally cupped flowers (Goldblatt et al., 1990). Recent molecular studies have shown that S. micranthum and $S$. rosulatum were in the same clade and they were closely related (Chauveau et al., 2011; Karst and Wilson, 2012; Alves et al., 2014).

One species in genus Sisyrinchium, Deung-Sim-But-Kkot ( $S$. rosulatum), was reported as invasive species in Korea (Chung et al., 1949; Jung, 1955). This taxon was found also in neighboring Japan and its scientific name has been commonly known as $S$. angustifolium Mill. in Korea and $S$. atlanticum E. P. Bicknell in Japan each. Both $S$. angustifolium and $S$. atlanticum are assigned to subgenus Sisyrinchium (Goldblatt et al., 1990). However, they have a fully fused filamental column which is the main characteristic of subgenus Sisyrinchium, and they are distinctly distinguished morphologically from DeungSim-But-Kkot.

Because of the morphological plasticity observed within $S$. micranthum and the lack of careful studies on S. rosulatum, the identification of the two species are often unclear and recent molecular studies suggested that both are a single species, i.e. S. micranthum (Chauveau et al., 2011; Tacuatiá et al., 2012; Tacuatiá et al., 2016). However, S. micranthum and $S$. rosulatum are native in Latin America and North America respectively (Cavanilles, 1788; Bicknell, 1899; Cholewa and Henderson, 2002; Goldblatt and Manning, 2008). Additionally, their morphological characteristics which are found in Korea show clear distinction in the size and shape of flowers, the height of plants, the width of leaves, and the size of fruits and seeds. In this paper, we report $S$. micranthum and $S$. rosulatum based on the type specimens (Figs. 1, 2), the original descriptions, and recent papers (Cavanilles, 1788; Bicknell, 1899; Chauveau et al., 2011; Karst and Wilson, 2012; Alves et al., 2014). We provide photographs to compare $S$. micranthum and S. rosulatum (Fig. 3) and the illustration of $S$. micranthum (Fig. 4).

Some plants of $S$. rosulatum, which have white tepals, have been previously reported as new forma, S. angustifolium for. album J. K. Sim \& Y. S. Kim in Korea (Sim and Kim, 1992). However, this new invasive forma reported is a white type of $S$. rosulatum or $S$. micranthum is not certain on account of lack of information in the voucher specimens and the original description. Consequently, we treat $S$. angustifolium and $S$. angustifolium for. album as synonyms of S. rosulatum.

\section{Taxonomic Treatment}

Sisyrinchium micranthum Cav. Diss. 6: 345, t. 191, f. 2, 1788; Marica micrantha (Cav.) Ker Gawl., Irid. Gen. 22, 1827; Bermudiana micrantha (Cav.) Kuntze Revis., Gen. Pl. 2: 700, 1891.-TYPE: MNHN-P-P00672523 (P).

Sisyrinchium iridifolium Kunth, Nov. Gen. Sp. 1: 324, 1816; Marica iridifolia (Kunth) Ker Gawl., Bot. Reg. 3: t. 229, 1817; Irid. Gen. 22, 1827; Bermudiana iridifolia (Kunth) Kuntze, Revis. Gen. Pl. 2: 699, 1891.

Sisyrinchium dichroum Poepp. ex Klatt, Fl. Bras. 3: 537, 1871.

Sisyrinchium fimbriatum Dombey ex Klatt, Fl. Bras. 3: 537, 1871.

Sisyrinchium micranthemum Pers., Syn. Pl. 1: 50, 1805.

Sisyrinchium micranthum f. eburneochraceum Ravenna, Onira 5: 57, 2001.

Sisyrinchium micranthum f. flavum Ravenna, Onira 5: 57, 2001.

Sisyrinchium micranthum f. luteum Ravenna, Onira 5: 58, 2001.

Sisyrinchium micranthum f. purpureum Ravenna, Onira 5: 57, 2001.

Sisyrinchium micranthum subsp. scudiculare Ravenna, Onira 5: 57, 2001.

Korean name: Yeon-Deung-Sim-But-Kkot (연등심붓꽃).

Herbs annual or short-lived perennial, $15-40 \mathrm{~cm}$ tall. Stems branched or rarely simple, flat, with 1-3 nodes, 1$3 \mathrm{~mm}$ wide, glabrous. Leaves alternate, ensiform, straight, 4-15 cm long, 3-6 mm wide, recurved at the apex. Inflorescences borne singly; spathes green, wider than supporting branch; outer spathes $2.5-4 \mathrm{~cm}$ long, $0.2-0.4 \mathrm{~mm}$ wide, margins basally connate $0.7-1.2 \mathrm{~cm}, 0-2 \mathrm{~mm}$ longer than inner one, apex acuminate, glabrous or hairy margin, hyaline margins of inner spathe ca. $0.3 \mathrm{~mm}$ wide. Flowers 


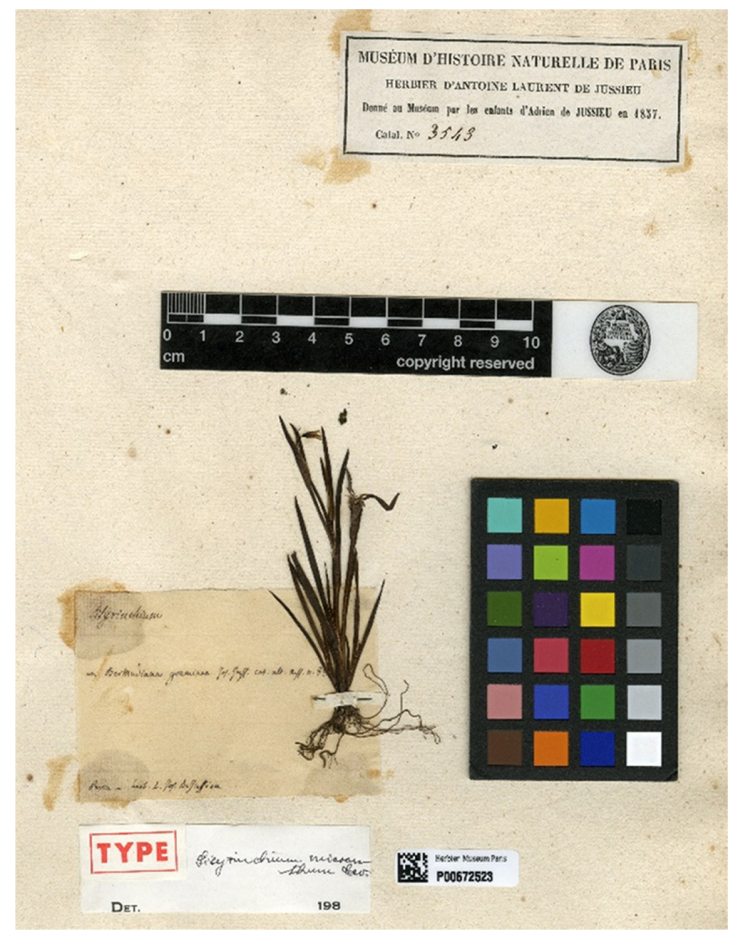

Fig. 1. Type specimen of Sisyrinchium micranthum Cav in National Museum of Natural History (France).

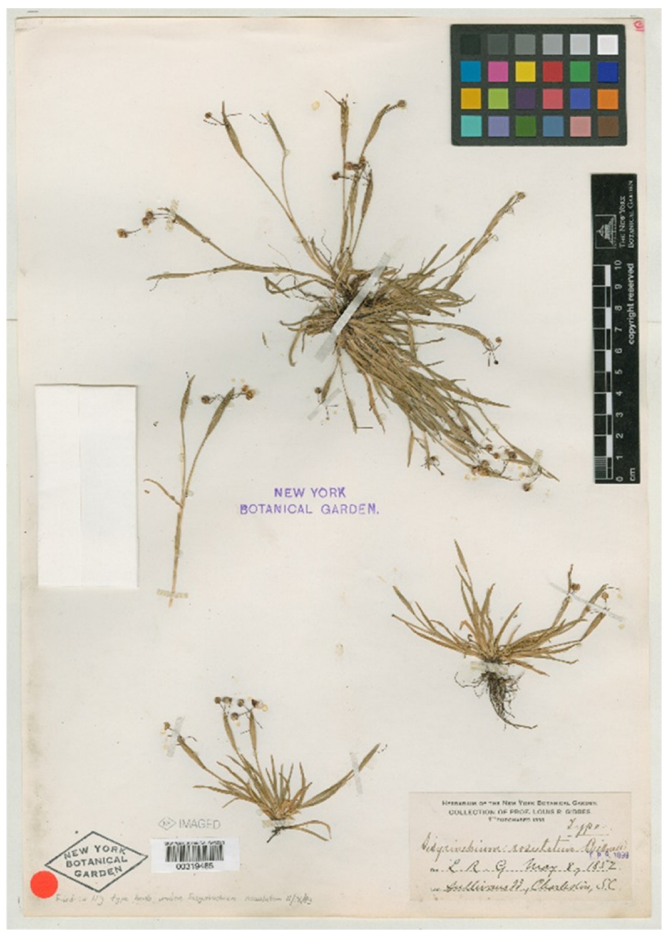

Fig. 2. Type specimen of Sisyrinchium rosulatum E. P. Bicknell in New York Botanical Garden.
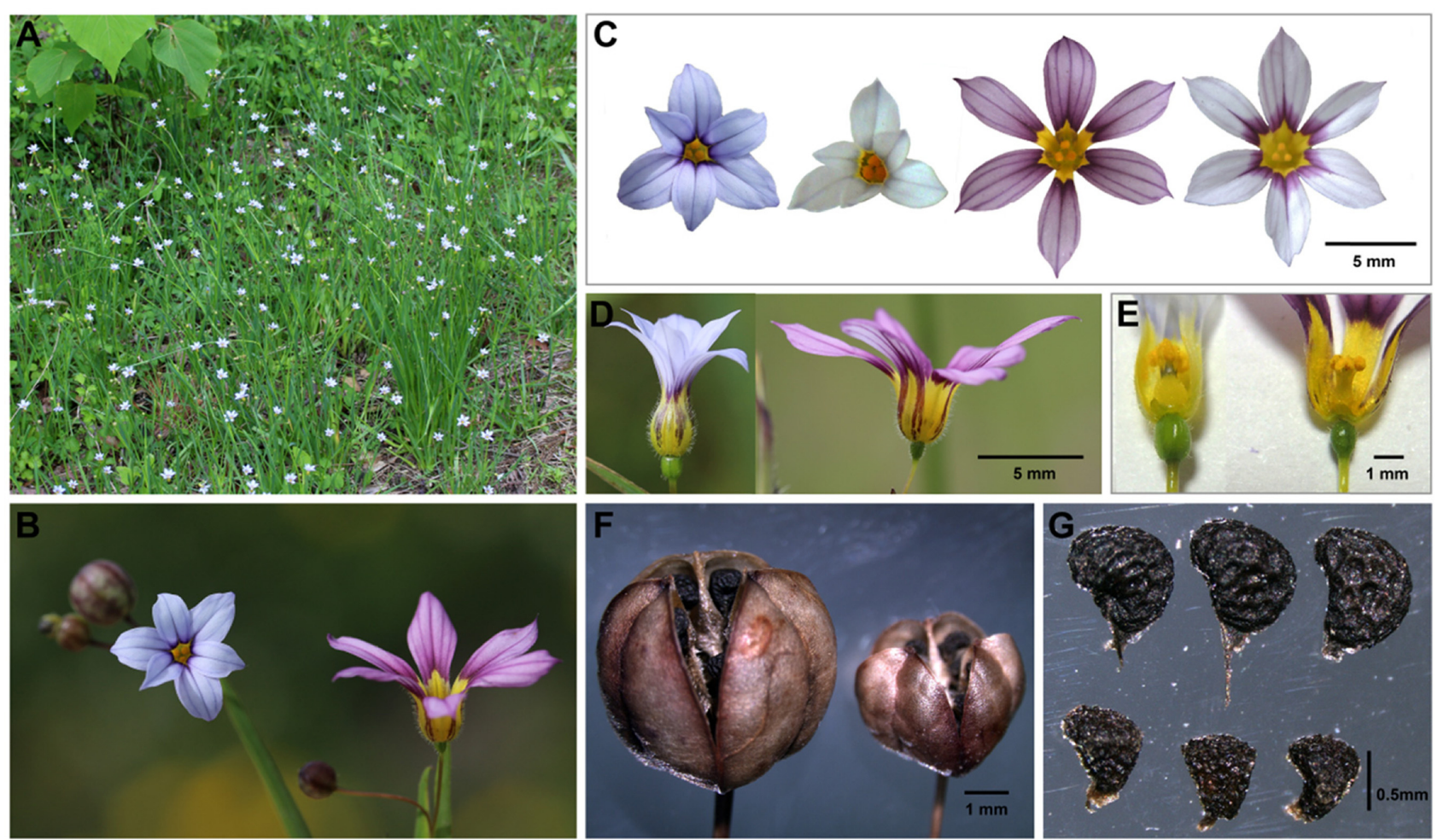

Fig. 3. Photographs of Sisyrinchium micranthum Cav. and S. rosulatum E. P. Bicknell. A. Habitat of S. micranthum. B. Two species in the same habitat. C. Flower comparison (from left to right) of S. micranthum (lavender type), S. micranthum (white type), S. rosulatum (purple type), and $S$. rosulatum (white type). D-F. Flower shapes, longitudinal sections of flowers, and fruit capsules of $S$. micranthum (left) and $S$. rosulatum (right). G. Seeds of S. micranthum (up) and S. rosulatum (down). 

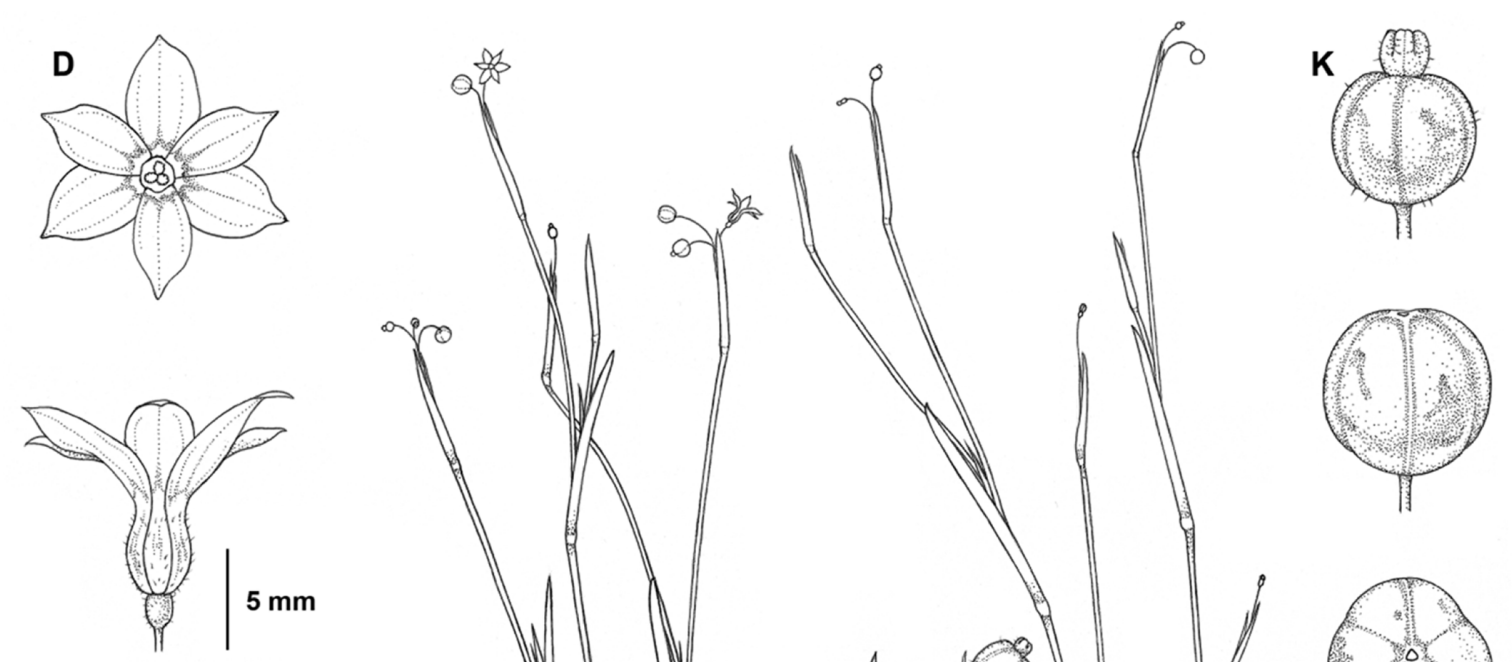

E
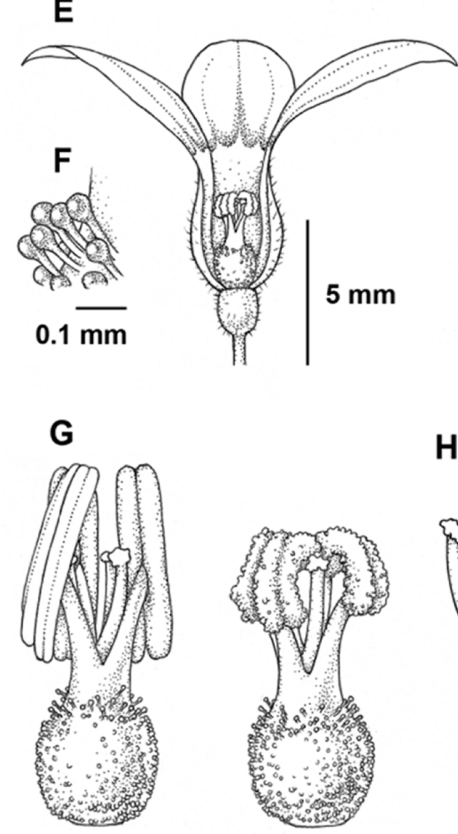

H
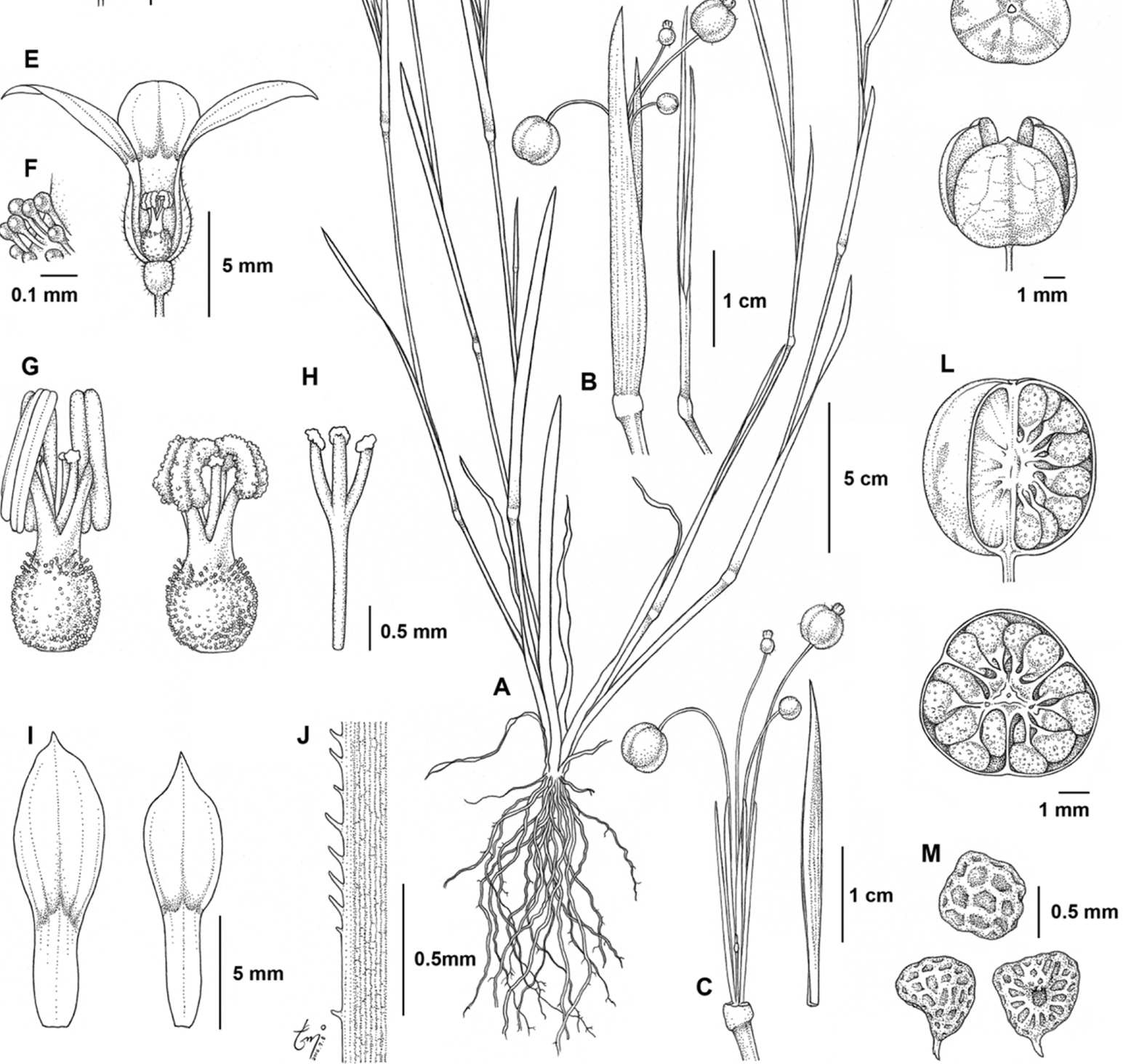

Fig. 4. Illustration of Sisyrinchium micranthum Cav. A. Flowering individual. B. Inflorescence (fruiting). C. Inflorescence and inner spathe. D. Flowers. E. Longitudinal section of a mature flower. F. Oil-glandular trichomes on the base of filamental column. G. Filamental column. H. Style. I. Tepals. J. Leaf margin. K. Fruit capsules. L. Longitudinal and latitudinal sections of immature fruit. M. Seeds. 
tepals lavender or white, with yellow center; flowers urceolate basally; outer tepals ca. $1 \mathrm{~cm}$ long, ca. $4 \mathrm{~mm}$ wide; inner tepals ca. $9 \mathrm{~mm}$ long, ca. $3 \mathrm{~mm}$ wide; filaments connate basally; glandular trichomes on the filamental column. Capsule ca. $5 \mathrm{~mm}$ in diam, globular, pubescent, or glabrous. Seeds ca. $1.1 \mathrm{~mm}$ long, alveolate, umbilicate, asymmetrically cuneate, and angled (Bicknell, 1899; Takeuchi et al., 2008). Chromosome number $2 \mathrm{n}=16,32$, or 48 (Tacuatiá et al., 2016).

Voucher specimens: KOREA. Jeju-do: Seogwipo-si, Namwon-eup, Seoseong-ro 810beon-gil, 2, 16 Jun 2016, $H$. W. Shin, M. J. Kim \& D. H. Kim s.n. (EWH); Seogwipo-si, Jijangsaem-ro, 331, 16 Jun 2016, H. W. Shin, M. J. Kim \& D. H. Kim s.n. (EWH); Seogwipo-si, 516-ro, 463, 16 Jun 2016, H. W. Shin, M. J. Kim \& D. H. Kim s.n. (EWH); Seogwiposi, Namwon-eup, 516-ro, 767, 16 Jun 2016, H. W. Shin, M. J. Kim \& D. H. Kim s.n. (EWH); Seogwipo-si, 516-ro, 652, 16 Jun 2016, H. W. Shin, M. J. Kim \& D. H. Kim s.n. (EWH); Seogwipo-si, 516-ro 771 beon-gil, 200, 16 Jun 2016, H. W. Shin, M. J. Kim \& D. H. Kim s.n. (EWH).

Collection site: Seogwipo-si, Jeju-do, Korea. $33^{\circ} 19^{\prime} 54.3^{\prime \prime} \mathrm{N} 126^{\circ} 40^{\prime} 45.1^{\prime \prime E}, 33^{\circ} 17^{\prime} 26.3^{\prime \prime} \mathrm{N} 126^{\circ} 33^{\prime} 10.2^{\prime \prime} \mathrm{E}$, $33^{\circ} 17^{\prime} 34.0^{\prime \prime} \mathrm{N} \quad 126^{\circ} 35^{\prime} 40.6^{\prime \prime} \mathrm{E}, \quad 33^{\circ} 18^{\prime} 58.0^{\prime \prime} \mathrm{N} \quad 126^{\circ} 35^{\prime} 48.7^{\prime \prime} \mathrm{E}$, $33^{\circ} 18^{\prime} 24.7^{\prime \prime N} 126^{\circ} 36^{\prime} 01.0^{\prime \prime E}, 33^{\circ} 19^{\prime} 45.2^{\prime \prime N} 126^{\circ} 35^{\prime} 06.3^{\prime \prime E}$.

Habitat: Disturbed area including lawn, roadside, village green, and construction area. Sisyrinchium micranthum is commonly found along sunny roadsides.

Distribution: Native in Central and South America.

Naturalized in Australia, Japan, New Zealand, Samoa, South Africa, and United States.

Naturalized in Namwon-eup and the whole neighborhood, Seogwipo-si, Jeju-do, Korea.

\section{Key to the species of genus Sisyrinchium in Korea}

1. Leaves 1-2.5 mm wide; flowers campanulate basally; tepals purple, violet, or white; capsule ca. $3 \mathrm{~mm}$ in diam.

S. rosulatum

1. Leaves 3-6 mm wide; flowers urceolate basally; tepals lavender or white; capsule ca. $5 \mathrm{~mm}$ in diam.

S. micranthum

\section{Acknowledgments}

This research was supported by the BK21 Plus Program (Creative Academy of Eco Science, 31Z20130012990) funded by the Ministry of Education and National Research Foundation of Korea. We thank Dr. Carol A. Wilson in University of California and Dr. Anita F. Cholewa in University of Minnesota.

\section{Literature Cited}

Alves, T. L. S., O. Chauveau, L. Eggers and T. T. de Souza?Chies. 2014. Species discrimination in Sisyrinchium (Iridaceae): assessment of DNA barcodes in a taxonomically challenging genus. Molecular Ecology Resources 14: 324-335.

Bicknell, E. P. 1899. Sisyrinchium rosulatum E.P. Bicknell. Bulletin of the Torrey Botanical Club 26: 228.

Cavanilles, A. J. 1788. Sisyrinchium micranthum Cav. Sexta Dissertatio Botanica Diss. 6: 345.

Chauveau, O., L. Eggers, C. Raquin, A. Silvério, S. Brown, A. Couloux, C. Cruaud, E. Kaltchuk-Santos, R. Yockteng, T. T. Souza-Chies and S. Nadot. 2011. Evolution of oil-producing trichomes in Sisyrinchium (Iridaceae): insights from the first comprehensive phylogenetic analysis of the genus. Annals of Botany 107: 1287-1312.

Cholewa, A. F. and D. M. Henderson. 1984. Biosystematics of Sisyrinchium section Bermudiana (Iridaceae) of the Rocky Mountains. Brittonia 36: 342-363.

Cholewa, A. F. and D. M. Henderson. 2002. Sisyrinchium. Flora of North America 26: 351-371.

Chung, T. H., B. S. Do, D. B. Lee and H. J. Sim. 1949. Nomina Plantarum Koreanum 1. Chosen Biology Society, Seoul, 235 p. (in Korean)

Cocucci, A. A. and S. Vogel. 2001. Oil-producing flowers of Sisyrinchium species (Iridaceae) and their pollinators in southern South America. Flora (Germany) 196: 26-46.

Esler, A. E. and S. J. Astridge. 1987. The naturalisation of plants in urban Auckland, New Zealand 2. Records of introduction and naturalisation. New Zealand Journal of Botany 25: 523-537.

Goldblatt, P., J. E. Henrich and R. C. Keating. 1989. Seed morphology of Sisyrinchium (Iridaceae-Sisyrinchieae) and its Allies. Annals of the Missouri Botanical Garden 76: 1109_ 1117.

Goldblatt, P., P. Rudall and J. E. Henrich. 1990. The genera of the Sisyrinchium Alliance (Iridaceae: Iridoideae): phylogeny and relationships. Systematic Botany 15: 497-510.

Goldblatt, P. and J. C. Manning. 2008. The Iris Family: Natural History and Classification. Timer Press, Portland, OR, 290 pp.

Jung, T. H. 1955. Sisyrinchium angustifolium Mill.. Korean Flora 2: 996.

Karst, L. and C. A. Wilson. 2012. Phylogeny of the New World genus Sisyrinchium (Iridaceae) based on analyses of plastid and nuclear DNA sequence data. Systematic Botany 37: 87-95.

Macdonald, I. A. W., J. K. Reaser, C. Bright, L. E. Neville, G. W. Howard, S. J. Murphy and G. Preston. 2003. Invasive Alien Species in Southern Africa. The Gloval Invasive Species Programme, Cape Town, 125 pp. 
Miyawaki, S. and I. Washitani. 2004. Invasive alien plant species in riparian areas of Japan: the contribution of agricultural weeds, revegetation species and aquacultural species. Global Environmental Research 8: 89-101.

Rudall, P., A. Y. Kenton and T. J. Lawrence. 1986. An anatomical and chromosomal investigation of Sisyrinchium and allied genera. Botanical Gazette 147: 466-477.

Sim, J. K. and Y. S. Kim. 1992. New taxa of Iridaceae from Korea. Korean Journal of Plant Taxonomy 22: 1-5.

Smith, N., S. A. Mori, A. Henderson, D. W. Stevenson and S. V. Heald. 2004. Flowering Plants of the Neotropics. Princeton University Press, Princeton, NJ, 594 p.

Souza-Chies, T. T., E. K. dos Santos, L. Eggers, A. M. Flores, E. M. S. Alves, J. Fachinetto, J. Lustosa, L. B. Corrêa, L. O. Tacuatiá, P. Piccoli and R. B. Miz. 2012. Studies on diversity and evolution of Iridaceae species in southern Brazil. Genetics and Molecular Biology 35: 1027-1035.

Space, J. C. and T. Flynn. 2002. Report to the Government of Samoa on Invasive Plant Species of Environmental Concern. USDA Forest Service, Pacific Southwest Research Station, Institute of Pacific Islands Forestry, Honolulu, HI, 78 pp.

Tacuatiá, L. O., T. T. Souza-Chies, A. M. Flores, L. Eggers, S. Siljak-Yakovlev and E. Kaltchuk-Santos. 2012. Cytogenetic and molecular characterization of morphologically variable Sisyrinchium micranthum (Iridaceae) in southern Brazil. Botanical Journal of the Linnean Society 169: 350-364.

Tacuatiá, L. O., E. Kaltchuk-Santos, T. T. Souza-Chies, L. Eggers, E. R. Forni-Martins, F. Pustahija, O. Robin and S. SiljakYakovlev. 2016. Physical mapping of 35S rRNA genes and genome size variation in polyploid series of Sisyrinchium micranthum and S. rosulatum (Iridaceae: Iridoideae). Plant Biosystems: An International Journal Dealing with all Aspects of Plant Biology 1-11.

Takeuchi, C., P. Affonso and N. S. Chukr. 2008. Levantamento de iridaceae Juss. no Núcleo Curucutu, Parque Estadual da Serra do Mar, São Paulo [Survey of the family Iridaceae Juss., in Curucutu Nucleous, Serra do Mar State Park, São Paulo]. Revista do Instituto Florestal, São Paulo 20: 51-53.

Weber, E. and D. Gut. 2004. Assessing the risk of potentially invasive plant species in central Europe. Journal for Nature Conservation 12: 171-179.

Wu, S.-H., C.-F. Hsieh, S.-M. Chaw and M. Rejmánek. 2004. Plant invasions in Taiwan: insights from the flora of casual and naturalized alien species. Diversity and Distributions 10: 349-362. 